\title{
Eminent Domain: The Perpetual Rights of the Indigenous People of Kenya to Land Ownership
}

\author{
Mitchel Ondili*
}

\begin{abstract}
The power of eminent domain, a facet of the powers vested in the Government of Kenya, is ideally a tool for conservation of the environment and the advancement of the public good. Unfortunately, this power has been abused over the years, and become a gateway for unscrupulous regimes to appropriate land. Consequently, the core right of indigenous people - the right to ownership of property, specifically land-has been violated and usurped time and time again to the end of eminent domain. Due to the unique nature of indigenous people and their identity, the power of eminent domain should be suspended from the prerogative of the Government for the sake of their protection and continuity.
\end{abstract}

\section{Introduction}

Anthropologist Ronald Niezen described indigenous people as those 'whose position in the modern world is least tenable'. ${ }^{1}$ The demands of this 'modern world' have rendered indigenous people the dregs of the tea of time from which those who opted to develop with the ages have sieved through somewhat seamlessly into the coming ages. This notion of being on the outskirts of society has led to shunning indigenous people by the larger society and consequently, denial of their rights.

In Africa, defining and delineating the rights of indigenous people has been especially difficult due to its unique history of indigeneity. ${ }^{2}$ In Kenya, particularly,

* The author is an LL.B student at the Strathmore University Law School in Nairobi, Kenya.

1 Niezen R, 'The origins of indigenism: Human rights and the politics of identity', 1ed, University of California Press, Berkeley, 2003, 5.

2 In other countries where indigenous people are recognised, there is an ongoing relationship with the colonisers. Africa forms an exception as independent Africa saw the return of nearly all colonisers to their origins necessitating a different understanding of what it meant to be indigenous. 
the right to own land is central to the rights-based claims of indigenous people. Land forms the basis from which the identity of indigenous people begins to be understood. ${ }^{3}$ The onset of even greater development threatens the right of indigenous people to own land because of the use of the power of the state to convert private or protected property to the needs of the state, otherwise known as eminent domain. ${ }^{4}$ In Kenya, this power is provided for under Article 40 of the Constitution $^{5}$ and Part VIII of the Land Act. ${ }^{6}$

This article proposes that the rights of indigenous people form an exception to the power of eminent domain. To elucidate this contribution, the article is broken down into three parts. The first details the complexity of defining indigenous people in Kenya due to the unique history of usurpation in Africa. The principal contribution of this part is the understanding of the shift in the definition of indigenous people and its application in Kenya. The second details the history of land acquisition prior to colonialism, during colonialism and following colonialism. Particularly, part two seeks to detail the development and use of the power of eminent domain by the colonial powers and the pervasion of colonial ideals and policies on independent Kenya leading to the polarisation that saw the formation of newly defined indigenous people and appropriation of their land. The third seeks to provide a view in which to examine the reasons behind the author's contribution that indigenous people require an exception to the doctrine of eminent domain.

\section{Defining Indigenous People}

The need to find a working definition of indigenous people in Kenya is twofold. First, the need to settle great debate as to whether indigenous people can be said to exist in Africa $^{7}$ and second, the specific need in Kenya, to distinguish indigenous people from similarly marginalised communities and groups in order to give prevalence to their rights.

\footnotetext{
Dersso S, Perspectives on the rights of minorities and indigenous peoples in Africa, Pretoria University Law Press, 2010, 43.

4 Kameri-Mbote P, 'The land question in Kenya: Legal and ethical dimensions', International Environmental Law Research Centre, Governance, 2009, 8.

Article 40, Constitution of Kenya (2010).

Land Act, 2015

— <http://www.iwgia.org/regions/africa/indigenous-peoples-in-africa> on 31 August 2015.
} 
In elucidating indigeneity, early definitions held that the term indigenous people' acquired substance when other populations could be described as aliens. ${ }^{8}$ To speak of indigenous people was to speak of a particular history of usurpation, ${ }^{9}$ or the idea of bringing identities of older populations into sharper relief by forcing them to remain apart, sometimes at the risk of extinction. ${ }^{10}$ Because of the existence of the categories of 'usurpers' and the 'usurped', the classic definition of indegenous people obtained for colonized Africa. However, self-determination rendered the definition of indigenous people in terms of the coloniser-colonised relationship, obsolete. ${ }^{11}$ This is because the majority of settlers fled back to their countries. ${ }^{12}$ The arrival and departure of the colonialists led to a polarisation of societies in Africa, between those who had adopted the way of the colonialists, and those who stuck to their original cultural roots. ${ }^{13}$ Therefore a new question arose in the indigenous people's forums. Could there exist indigenous people ${ }^{14}$ in an area inhabited entirely by 'first people ${ }^{15}$ but had suffered the aforementioned extreme polarisation? For several years forums on indigenous people did not think so. ${ }^{16}$

Perhaps the first international forum to recognise the possibility of the existence of indigenous people in Africa was the United Nations Working Group on Indigenous Peoples. In 1989, the Working Group recognised African representatives in an address by a Maasai activist, Moringe Ole Parkipuny, in Geneva, Switzerland. ${ }^{17}$ Parkipuny's idea of indigenous people in Africa had come about while contemplating how to provide a voice for the struggling Maasai community. He realised that groups all over Africa suffered commonly from land alienation, forced settlement, deep disparities in the provision of social services like education and health, cultural disparagement and at times efforts at forced assimilation. $^{18}$

\footnotetext{
Van Dyke V, 'Self-determination and minority rights,' International Studies Quarterly, 1969, 252.

Beteille A, 'The idea of indigenous peoples', 39, Current Anthropology (2), 1998, 188.

Beteille A, 'The idea of indigenous peoples', 188.

11 Dersso S, 'Perspectives on the rights of minorities and indigenous peoples in Africa', Pretoria University Law Press, 2010, 43.

12 <http://www.nationalarchives.gov.uk/education/empire/g3/cs2/background.htm> on 31st August 2015.

13 Hodgson D, 'Becoming indigenous in Africa', African Studies Review, 3, 2009.

14 Hodgson D, 'Becoming indigenous in Africa', 3.

15 Here 'first people' are taken to mean the earliest known inhabitants of the area.

16 Beteille A, 'The idea of indigenous peoples', 188.

17 Hodgson D, 'Becoming indigenous in Africa', 1.

18 Hodgson D, 'Becoming indigenous in Africa', 3.
} 
He spoke about the plight of indigenous people in Africa stating that the concept had come about as a result of the ramifications of the effect of colonialism and subsequent neo-colonialism. He stated that due to this shift, the new wave of Africans declaring solidarity for themselves caused a double-edged sword effect of creating great prejudices against the rights of those who lived a lifestyle dissimilar to those of the majority of the national population. This was especially prevalent among the hunter-gatherers and the pastoralists. Parkipuny argued that though they did not share the characteristic of being 'first peoples' they shared structural similarities such as political subjugation, economic marginalisation, territorial dispossession and cultural and linguistic discrimination by colonial and then postcolonial states. ${ }^{19}$

This speech began the discussion on whether or not certain groups of Africans could be termed as indigenous, challenging previous definitions of the word. The discussions revealed inherent hypocrisies in African nations, for instance the irony of the majority of assimilated postcolonial Africans using colonial stereotypes to defend their rights and resources and justify creating unfair stereotypes and disparity. ${ }^{20}$

The results of these discussions began to be acknowledged. In the Indigenous and Tribal Peoples Convention No 169, ${ }^{21}$ the aspirations of indigenous people were noted to be dissimilar to those of previous years. Where those aspirations were once concerned with integration and assimilation, they changed to recognition and development of their identities. ${ }^{22}$ The denotation of indigenous peoples then shifted from one of 'first persons' to one of culturally distinct people. ${ }^{23}$ Indigenous people are now described as those who historically resisted colonialism, state formation and global capitalism and remain connected to their cultural traditions. $^{24}$

Another more elaborate definition would be:

'Indigenous communities, peoples and nations are those which, having a historical continuity with pre-invasion and pre-colonial societies that developed on their territories, consider themselves distinct from other sectors of the societies now prevailing in those

\footnotetext{
Hodgson D, 'Becoming Indigenous in Africa', 52, African Studies Review 3, 2009.

Hodgson D, 'Becoming Indigenous in Africa', 3.

Hereafter referred to as the ITP Convention.

Hodgson D, 'Becoming Indigenous in Africa', 10.

Campbell J, 'Ethnic minorities and development: a prospective look at the situation of African pastoralists and hunter-gatherers' Ethnicities, 2004, 9.

24 Igoe J, 'Indigenous peoples: Difference, inequality and globalisation of East African identity politics' 105 African Affairs, 2006, 402.
} 
territories, or parts of them. They form at present non-dominant sectors of society and are determined to preserve, develop and transmit to future generations their ancestral territories and their ethnic identity as the basis of their continued existence as peoples, in accordance with their own cultural patterns, social institutions and legal systems. ${ }^{25}$

Following these changed general guidelines, it is now possible to answer the question of whether there are indigenous people in Kenya.

\section{i. Indigenous people in Kenya}

As a result of the partition of Africa, different ethnic groups in Kenya were lumped together and cordoned off from previously established territories. ${ }^{26}$ This caused the formation of several tribal groupings with the majority tribes being the most advantaged.

In a report by the Truth, Justice and Reconciliation Commission (TJRC), set up to handle the injustices that had taken place between 1963 and 2008, it was noted that the State failed to recognise minority groups and indigenous people specifically those residing in then North Eastern, Rift Valley and Coast provinces of Kenya. ${ }^{27}$ It was also stated that the State conducted 'oppressive security operations' in pastoralist areas so aggressively that some of them amounted to crimes against humanity, for instance, the Wagalla massacre. ${ }^{28}$

\section{ii. Ethnic considerations in the formation of indigenous people in Kenya}

\section{a. Recognition}

In the census carried out by the Kenya National Bureau of Statistics (KNBS), the population of Kenya is divided into roughly 42 groups, groups which categorise themselves as distinct and indigenous are classed under larger groups. ${ }^{29}$ For instance, the Ogiek and the Endorois are grouped under the Kalen-

25 Report of the Special Rapporteur on the study of the problem of discrimination against indigenous populations, Jose Martinez, Cobo, 1986/87, UN doc E/CN.4/sub.2/1986/7.

26 — - http://responsibilitytoprotect.org/Kenyapercent20reportpercent20Jan12percent202011.pdf on 31August 2015.

27 <http://digitalcommons.law.seattleu.edu/tjrc/ > on 31 August 2015.

$28<$ http://digitalcommons.law.seattleu.edu/tjrc/ > on 31 August 2015.

29 <http://www.knbs.or.ke/index.php?option=com_content\&view=article\&id=151:ethnic-affiliation \&catid $=112 \&$ Itemid $=638>$ on 16 February 2016. 
jin. ${ }^{30}$ The danger of this 'assimilation' of smaller distinct groups into larger ones is that it provides an avenue for bypassing addressing the rights of indigenous people. $^{31}$

In the case of Rangal Lemeiguran and others $v$ Attorney General and others, brought to the High Court by representatives of the Ilchamus community, which recognises itself as an indigenous community, the issue of recognition was tackled. The applicants stated that they were an indigenous community that had been without representation in Parliament since independence. They further stated that they are one of the few communities recognised in international law as an indigenous yet the rights that come with that classification had been overlooked and ignored by the State. The material words state:

"With respect to the issue of recognition, the court declared that the minority interests constitute special interests as contemplated by the purposes of Section 33 of the former Constitution of Kenya which stated that 'subject to this section, there shall be twelve nominated members of the National Assembly appointed by the President following a general election, to represent special interests'." 32

The Constitution of Kenya (2010) has attempted to address the issue of recognition and representation in various ways. The 2010 Constitution provides for the interests of minority and marginalised groups averring in part that the State is responsible for ensuring that minorities and marginalised groups participate and are represented in governance. ${ }^{33}$ Further, the 2010 Constitution states that Parliament shall enact legislation to provide for representation of ethnic minorities, other minorities and marginalised communities. ${ }^{34}$ Additionally, some of the objectives of devolution are to ensure protecting and promoting the interests of minorities and marginalised groups. ${ }^{35}$

The Universal Declaration on Human Rights (UDHR) states that everyone has the right to recognition, ${ }^{36}$ to a nationality, ${ }^{37}$ and to take part in the government of their country, directly or through representatives. ${ }^{38}$ Article 6 of the

\footnotetext{
${ }^{30}-<$ http://www.knbs.or.ke/index.php?option $=$ com_content\&view $=$ article\&id=151:ethnic-affiliati on\&catid=112\&Itemid $=638>$ on 16 February 2016.

— <http://minorityrights.org/minorities/hunter-gatherers/> on 14 December 2016.

Rangal Lemeiguran and others v Attorney General and others (2004) eKLR.

Article 56, Constitution of Kenya (2010).

Article 100, Constitution of Kenya (2010).

Article 174, Constitution of Kenya (2010).

Article 6, Universal Declaration of Human Rights, 10 December 1948, GAR 217 A.

Article 15, Universal Declaration of Human Rights, 10 December 1948, GAR 217 A.

Article 21, Universal Declaration of Human Rights, 10 December 1948, GAR 217 A.
} 
Indigenous and Tribal Peoples' Convention (ITP Convention), instils a duty in the governments of the countries that have ratified it to involve the concerned communities whenever decisions affecting them are being made as well as cater for the community's developmental needs. ${ }^{39}$

Despite these measures and provisions, indigenous people still suffer political marginalisation, at times exacerbated by the Government ${ }^{40}$ as well as due to lack of implementation of court decisions such as in the decision in the Ilchamus case. $^{41}$

\section{b. Discrimination}

The colonial government adopted a divide and rule approach that instigated the negative ethnic dynamic that still affects Kenya today. ${ }^{42}$ At independence, the foremost characteristic of the dominant political parties was their ethnicity. The postcolonial governments only seemed to be too happy to fuel the existing negativity. Jomo Kenyatta and Daniel arap Moi regimes unabashedly favoured the Kikuyu and Kalenjin, respectively, ${ }^{43}$ the long-term results being the high degree of ethnic discrimination in Kenyan society. ${ }^{44}$ Because of the issue of ethnic rule by virtue of majority, indigenous peoples are often shunted to the side and passed over in economic, social and political contexts. ${ }^{45}$ This has led to the ethnification of political and economic processes. This is to say that ethnicity has become an inextricable part of Kenyas society and influences choices in governance, working environment and goes as far as social constructs such as marriage. ${ }^{46}$ Kenya is made up of over 40 different ethnicities and due to the multi-faceted nature of the communities, several of the lesser communities are not recognised or labelled as indigenous because, more often than not, they are recognised as sub groups of larger communities and not as culturally distinct communities. ${ }^{47}$ Part of Justice

\footnotetext{
Article 6, Indigenous and Tribal Peoples Convention, 27 June 1989, ILO No. 169.

40 Report of The Equal Rights Trust in partnership with the Kenya Human Rights Commission, In the Spirit of Harambee, Addressing discrimination and inequality in Kenya by Jim Fitzgerald, February 2012, 68.

${ }^{41}<\mathrm{http}: / /$ digitalcommons.law.seattleu.edu/tjrc/> on 31 August 2015.

$42<$ http://digitalcommons.law.seattleu.edu/tirc/ > on 31 August 2015.

43 Nowrojee B, 'Divide and Rule, State sponsored ethnic violence in Kenya' Africa Watch, 1993, 7-8.

44 <http://digitalcommons.law.seattleu.edu/tjrc/ > on 31 August 2015.

45 <http://www.chr.up.ac.za/chr_old/indigenous/documents/Kenya/Report/Kenya_Cemiride_Report.pdf $>$ on 31 August 2015.

46 <http://www.chr.up.ac.za/chr_old/indigenous/documents/Kenya/Report/Kenya_Cemiride_Report.pdf $>$ on 31 August 2015.

47 <http://www.chr.up.ac.za/chr_old/indigenous/country_reports/Country_reports_Kenya.pdf $>$ on 31 August 2015.
} 
Aaron Ringera's verdict in the case of Timothy Njoya v Attorney General and Others read as follows:

'...The concepts of equality of all before the law, citizens' rights in a democratic state, and of the fundamental norm of non-discrimination all call for equal weight for equal votes and the dictates that minorities should not be turned into majorities in decision making bodies of the State... That cannot however be the only consideration in a democratic society. The other consideration is that minorities of whatever tribe and shade are entitled to protection. And in the context of constitution-making, it is to be remembered that the constitution is being made for all, majorities and minorities alike, and accordingly, the voice of all should be heard' ${ }^{48}$

The discriminatory acts perpetuated against indigenous people, in part due to their being a minority, have contributed to the usurpation of their rights. A 'crowding out' effect by other communities has seen the underrepresentation of indigenous people and therefore little opportunity to give audience to their grievances. ${ }^{49}$

\section{Land ownership}

Land politics have been a major thorn in the side of development of Kenya and are the greatest driver of conflicts and ethnic tension in Kenya. ${ }^{50}$ At independence, it seemed as though the land that had been taken from indigenous communities would finally be restored. Instead, the Government picked up where the colonialists had left off. The Government appropriated land that was owned under the previous colonial order and continued to deprive existing communities of their land rights. ${ }^{51}$ Communities that have their land situated in areas with minerals suffer even more greatly as often the land is leased to foreign companies for mining purposes. ${ }^{52}$ To add insult to injury, where there is a conflict between protecting the land rights of indigenous people and setting up conservations, protection of wildlife has been preferred to the protection of these communities. ${ }^{53}$ Restrictions on hunting have also been put on indigenous people which limits the exercise of their culture. ${ }^{54}$ This has worsened the situation.

\footnotetext{
48 Njoya and Others $v$ Attorney General and Others (2004) AHRLR 157, 215-216.

49 — < http://minorityrights.org/minorities/hunter-gatherers/>on 14 December 2016.

Constitution of Kenya Review Commission, Final draft, 2005, 270.

Constitution of Kenya Review Commission, Final draft, 2005, 270.

Constitution of Kenya Review Commission, Final draft, 2005,256.

Constitution of Kenya Review Commission, Final draft, 2005, 256.

4 — < http://minorityrights.org/minorities/hunter-gatherers/>on 14 December 2016.
} 


\section{iii. Defining indigenous people in Kenya}

Perhaps the earliest mention of indigenous people in Kenya came up in the case brought before the African Human Rights Commission of the Centre for Minority Rights Development ${ }^{55}$ and Minority Rights Group on behalf of the Endorois Welfare Council. The case concerned incessant evictions of the Endorois from their land without their consent despite the area around Lake Bogoria being a major cultural hub for the community. The African Commission (AC) noted that "the term "indigenous" is also not intended to create a special class of citizens, but rather to address historical and present-day injustices and inequalities ${ }^{56}$

It was noted, more specifically, that

'there is an emerging consensus on some objective features that a collective of individuals should manifest to be considered as "peoples"... what is clear is that all attempts to define the concept of indigenous peoples recognise the linkages between peoples, their land, and culture and that such a group expresses its desire to be identified as a people or have the consciousness that they are a people.'

The AC noted, in part, that the Endorois could sufficiently be classed as an indigenous community and were entitled to benefit from provisions of the African Charter concerning the protection of collective rights. ${ }^{57}$

In seeking better criteria for defining indigenous people in Kenya, a meeting of experts comprising in part of members from the Kenya National Commission on Human Rights (KNCHR) and the Centre for Minority Rights Development (CEMIRIDE) suggested that indigenous people are those that collectively claim ancestral land, retain their traditional identity and customs, endure discrimination from the larger population and are unique in their spirituality and livelihood. ${ }^{58}$

The 2010 Constitution of Kenya does not define indigenous people. Rather, it groups indigenous people under marginalised communities, stating that a marginalised community would be considered 'an indigenous community that has retained and maintained a traditional lifestyle and livelihood based on a hunt-

\footnotetext{
55 Hereafter referred to as the AHCPR.

56 ACHPR 2010, para 149.

57 Centre for Minority Rights Development (Kenya) and Minority Rights Group International (on behalf of Endorois Welfare Council) v the Republic of Kenya-

<http://www.achpr.org/files/sessions/46th/comunications/276.03/achpr46_276_03_eng. pdf $>$ on 31 August 2015.

58 — < http://www.chr.up.ac.za/chr_old/indigenous/country_reports/Country_reports_Kenya.pdf $>$ on 31 August 2015.
} 
er or gatherer economy. ${ }^{59}$ However, while it is a giant leap for the recognition of indigenous people, this broad definition poses the risk of many seeking protection as marginalised groups and being ineffective in protecting 'real' indigenous people. ${ }^{60}$

The ITP Convention, which Kenya has ratified, states that it applies to:

'Tribal peoples in independent countries whose social, cultural and economic conditions distinguish them from other sections of the national community, and whose status is regulated wholly or partially by their own customs or traditions or by special laws or regulations. ${ }^{61}$

These definitions and criteria help establish the basis for dealing with indigenous people in Kenya. For the purposes of this paper the definitions alluded to in the 2010 Constitution and that provided in the ITP Convention will be adopted owing to the fact that the former is primarily authoritative in Kenya, and the latter is more concrete.

\section{Eminent Domain and the Land Situation in Kenya}

Customary law governed land ownership in pre-colonial times. Different communities had organised systems of property ownership. Designated bodies of authority oversaw the conferral of rights to what could be considered semiprivate property as prescribed by the law. These rights were flexible due to the shifting nature of the circumstances that various communities found themselves in. ${ }^{62}$ Besides the system of semi-private ownership of property, there was also a system of communal ownership of property, specifically land ownership, by the community. This system was defined by three characteristics; that the land was held for all generations, the land was managed at different levels of social organisation, and the land use was function-based..$^{63}$

59 Article 260, Constitution of Kenya (2010).

${ }^{60}$ - < http://responsibilitytoprotect.org/Kenyapercent20reportpercent20Jan12percent202011.pdf > Report for Minority Rights Group International ,Kenya at 50, Unrealized Rights of minorities, Korir Sing'oei Abraham, January 2012, 7.

61 Indigenous and Tribal Peoples Convention, 27 June 1989, ILO No. 169.

62 — < https://drive.google.com/a/strathmore.edu/file/d/0B0ijlt9hnVIvb3g2V1lYVGFua00/view>, Report of the Commission of inquiry into the Illegal/ Irregular Allocation of Public Land, 17 December 2004, 2.

63 Okoth-Ogendo HWO, 'The tragic Africa commons: a century of expropriation, suppression and subversion', 2002, 2-3 — < http://dlc.dlib.indiana.edu/dlc/bitstream/handle/10535/8098/Thepercent20Tragicpercent20Africanpercent20Commons.pdf? sequence $=1>$ on 27 July 2016. 
The onset of colonialism wrought the near entire erosion of the legitimacy of customary land tenure systems. ${ }^{64}$ After declaring Kenya a protectorate in 1895, the British began to apply common law principles to legitimise the appropriation of land in their declared territory. ${ }^{65}$ The colonial period was marked by the disenfranchisement of the rights of indigenous Kenyans in three ways. First, the diminishing of customary law and customary land tenure systems, ${ }^{66}$ the inequitable distribution of land where few landholders held great tracts of land and third, the inequitable development whereby only areas considered to be of fertile land or strategic value were developed while those on the opposite end, mainly given to indigenous Kenyans for settlement, were neglected. ${ }^{67}$

In 1960, with independence on the horizon, the colonial Government began a settlement plan for the Africanisation of the White Highlands and legislated guarantees to property rights that would see them protected even in the event of independence. ${ }^{68}$ The settlement scheme had been initiated under the guise of returning land to Africans that had been displaced during colonisation but ended up benefitting the elite Africans. A double effect of this settlement scheme was the intention to familiarise the African elites with the social, political and economic systems of land functioning and use in Europe to maintain their loyalty and ensure that the European property rights were secured post-independence. The scheme was based on a willing buyer willing seller model and benefitted the politicians (who belonged to the majority ethnic groups) and colonial sycophants further empowering the elite Africans and disenfranchising those who could not buy that which they may have historically been entitled to. ${ }^{69}$

${ }^{64}$ — < https://drive.google.com/a/strathmore.edu/file/d/0B0ijlt9hnVIvb3g2V1lYVGFua00/view>, Report of the Commission of inquiry into the Illegal/ Irregular Allocation of Public Land, 2004, 2.

65 Okoth Ogendo HWO, The Tragic African Commons: A century of expropriation, suppression, and subversion, 2002.

66 - < http://www.ielrc.org/content/a0910.pdf > on 31 July 2016.

Previous community held land, classified by Okoth-Ogendo as res communis, that is rights that were beld and enforced communally,was declared to be res nullus (that is, void) therefore whatever happened to it and the people on it was at the behest of the colonial government.

${ }^{67}-<$ http://www.ielrc.org/content/a0910.pdf > on 31 July 2016.

This also illustrates the abuse of the power of eminent domain by the colonial powers; the question of advancing public interest was viewed when considering whose public interest was being advanced.

68 Leo C, 'Who benefitted from the Million Acre Scheme? Toward a class analysis of Kenya's transition to independence' Canadian Journal of African Studies, 1981, 201-222.

69 Syagga P, 'Public land, historical land injustices and the new Constitution' 'The Society for International Development, Constitutional Working Paper Series Number 9, 2011,’ 10. 
It is necessary to note that at all moments prior to independence and the departure of the settlers, all the indigenous Kenyans could be classified as indigenous people owing to the original understanding of the term. ${ }^{70}$

The decolonisation process in Kenya, was characterised by a twofold hidden intention; that the colonial power should maintain a firm if unseen hold on the land rights acquired while they were the colonial masters and that the Kenyan elites attempt to further their individual goals, the consequence of which was the large appropriation of land from the less dominant tribes. ${ }^{71}$ Post-independent Kenya was marked by the abuse of the law to further the agenda of the ethnic majority most notably on the issue of land. ${ }^{72}$ The independence constitution sanctioned the taking of land for public use or public interest and additionally allowed the taking of land to be held in trust, a measure that greatly allowed for the further appropriation of land. ${ }^{73}$ At independence the land that was previously termed as native reserves was converted to trust land. Trust land was vested in the county councils and would lose its 'trust' status upon registration. ${ }^{74}$

At independence, three main political parties were actively contesting the general elections as allowed by the constitution, which, then, favoured a multiparty system. ${ }^{75}$ The Kenya African National Union (KANU) and African People's Party (APP) were dominated by the larger ethnic groups, mainly the Kikuyu, the Luo and the Kalenjin. ${ }^{76}$ The ascent to political power of Kenyan elites was largely linked to ethnic affiliation. ${ }^{77}$ Once in power, a relentless campaign of amassing and allocating land based on the misuse of the power of eminent domain was experienced during the various regimes. ${ }^{78}$

Besides the appropriation of land, the Government also began to encroach on land occupied by indigenous people for conservation purposes. These efforts

\footnotetext{
Beteille A, 'The idea of indigenous peoples', 188.

Syagga P, 'Public land, historical land injustices and the new Constitution', 10.

Nowrojee B, 'Divide and rule, State sponsored ethnic violence in Kenya' Africa Watch, 1993,7-8.

Article 75(6), Constitution of Kenya (1963).

4 — < http://www.chr.up.ac.za/chr_old/indigenous/documents/Kenya/Report/Kenya_Cemiride_ Report.pdf > on 31 August 2015. The Trust Land Act provided an avenue for the government to manipulate the uses of this land of which its original purpose was registration. The Transfer of Property Act of India (1882), the Registered Land Act (cap 300) and customary law guided land allocation together with The Registration of Documents Act, the Registration of Titles Act, The Government Lands Act, the Land Titles Act and the Registered Land Act supported this purpose.

75 Nowrojee B, 'Divide and Rule, State sponsored ethnic violence in Kenya' Africa Watch, 1993, 6.

76 Nowrojee B, 'Divide and rule, state sponsored ethnic violence in Kenya', 6.

77 Nowrojee B, 'Divide and rule, state sponsored ethnic violence in Kenya', 6.

78 Syagga P, 'Public land, historical land injustices and the new Constitution', 9-10.
} 
included the 1968 Forest Preservation Policy, the National Food Policy and the Nyayo Tea Zones. While valuable to the economy, these enactments allowed the Government to use the power of eminent domain to take land from communities that relied on it for sustenance and identity purposes. Attempts to involve local communities in the planning for and allocation of land fell short of fully addressing the grievances of the respective communities. ${ }^{79}$ Various commissions were set up to address the pressing land issues. The specific alienation of the rights of indigenous people to ownership of land was most prominently observed in the National Land Policy of 2009. The Policy laid out the rights of communities that lived within the forests as well as recognised community land ownership. ${ }^{80}$

Additionally, the Commission for the Review of the Constitution of Kenya pinpointed the need to protect the rights of marginalised communities such as indigenous people. ${ }^{81}$ The result was the introduction of community land in the constitution of Kenya. The constitution now has several provisions emphasising the need to recognise and protect rights of marginalised groups. Article 40 deals with general land rights, stating that every person has a right to acquire and own any property in any part of the country. This article also states that the State has no right to deprive a person of his or her right to property. If interference is absolutely necessary, the State should promptly compensate the person and allow anyone with an interest access to a court of law to dispute seizing of their property. ${ }^{82}$ Chapter 5 of the constitution is entirely devoted to addressing the issues of land and the environment. Of particular interest is Article 63 which provides fro community land. The constitution recognises, in part, that land occupied by hunter-gatherer communities forms community land. Of importance is the recognition of community land as a form of land tenure held collectively by the communities. ${ }^{83}$ The Land Registration Act also allows for registration of title to communities. ${ }^{84}$

The ITP Convention also addresses the issue of land. Part two of the convention states that governments shall respect the importance of the land of indigenous people to them, ${ }^{85}$ they shall identify and recognise their rights to

\footnotetext{
79 Kariuki F, 'Securing Land Rights in Community Forests: Assessment of Article 63 (2) (d) of the Constitution' published LLM Thesis, University of Nairobi, Nairobi, 2013, 17.

80 National Land policy (2009).

81 Constitution of Kenya Review Commission, Final draft, 2005, 256.

82 Article 40, Constitution of Kenya (2010).

83 Article 63, Constitution of Kenya (2010).

84 Section 9, Land Registration Act (Act No 3 of 2012).

85 Article 13, Indigenous and Tribal Peoples Convention, 27 June 1989, ILO No. 169.
} 
ownership and possession of the land, resolve land related conflicts and protect specially the resources of indigenous and tribal people. ${ }^{86}$ The convention states that dispossession of land should only be done where their relocation is absolutely necessary and must be consented to. ${ }^{87}$ Although there is extensive legislation that seems to sort out the issue of land, minority groups are yet to be compensated for the land they lost during the colonial and post-colonial time. ${ }^{88}$

In the case of Joseph Letuya and 21 others $v$ the Attorney General and 5 others, ${ }^{89}$ members of the Ogiek community brought a case to the High Court claiming violation of their land rights. Although the suit was filed in 1997, when the former constitution was in place, the injustices continued well after the enactment of the 2010 Constitution and therefore its provisions also applied. The applicants stated that they were continuously being evicted from their ancestral home and though they did not hold title deeds, they were entitled to protection of their land as it was a means of livelihood. Further, they argued that taking away their means of livelihood would be indirectly taking away their right to life. The court held that their right to life and freedom from discrimination had been violated and that the evictions were depriving them of their livelihood and that they should be allocated land to settle on.

\section{Against Eminent Domain}

The fragility of the existing indigenous communities such as the Ogiek, Sengwer and Endorois demands that special attention be paid to their rights. They have faced a struggle to be recognised as attempts at forced assimilation have been wrought upon them and the fact that they are minorities has led to underrepresentation in Government, contributing enormously to the delay in addressing their rights. ${ }^{90}$ They have been denied rights of ownership to their land from the pre-colonial era and despite the measures put in place to safeguard them, still have their livelihood threatened due to the power of eminent domain held by the Government. ${ }^{91}$

\footnotetext{
Article 15, Indigenous and Tribal Peoples Convention, 27 June 1989, ILO No. 169.

Article 15, Indigenous and Tribal Peoples Convention, 27 June 1989, ILO No. 169.

Report of the TJRC,2013,9.

Joseph Letuya and 21 others v Attorney General and 5 others [2014] eKLR.

— $<$ http://www.chr.up.ac.za/chr_old/indigenous/country_reports/Country_reports_Kenya.pdf > on 31 August 2015.

91 Dersso S, Perspectives on the rights of minorities and indigenous peoples in Africa, 316.
} 
Identity for these communities begins and ends with their land. Yet over time their land has been appropriated and allocated for use without their consent. The concepts of compensation cannot apply as the links to their land cannot be moved from one territory to another. The 2010 Constitution prohibits the deprivation of property by the State unless the land has been acquired by the State for a public purpose. It provides for compensation for the affected property owners as well as recourse in a court of law. ${ }^{92}$ However, the sheer weight of the identity of indigenous people in connection with their land must take into account that it would be all but impossible to duly compensate for such losses.

The power of eminent domain has empowered the Government to claim and take the land of indigenous people for its use, against the rights of indigenous people. In weighing the balance of the public good against the welfare of these communities, it has been decided time and time again that their interests are secondary to the interests of the State. For instance, the Sengwer people living in the Embobut Forest in the Rift Valley in Kenya have been forcibly evicted as a result of water and forest conservation efforts several times. The United Nations Special Rapporteur on the rights of indigenous people urged that this be stopped, after consideration of the effect that this would have on the people living in the forest. ${ }^{93}$ Rather than wait for the Government to get it right it is necessary to put measures in place to ensure that these extremely vulnerable communities are protected regardless of the whims of incoming and outgoing governments. Even where the notion of the use of communal land is for legitimate public good, it does a far greater injustice to indigenous people whose identities are inextricable from their land. ${ }^{94}$ Securing perpetual land rights can be ensured through the lens of a trilateral formula.

\section{v. The Way Forward}

In a technical meeting of the OAS Working Group a tripartite approach to indigenous people's rights with respect to eminent domain was proffered as follows:

'...Inembargability, the principle that land cannot be impounded or auctioned for debts; imprescriptibility, the theory that land rights cannot be subject to any statute of limitations; and inalienability, the concept that land cannot be transferred to third par-

\footnotetext{
92 Article 40, Constitution of Kenya (2010).

93 — $\mathrm{http}: / /$ www.un.org/apps/news/story.asp?NewsID=46914\#.V7Bt2yh97IW > on 1August 2015.

94 Maranga M, Indigenous people and the roles of culture, law and globalization: comparing the Americas, AsiaPacifics and Africa, Universal Publishers, Florida, 2013, 28.
} 
ties outside the Indigenous People or collective. These legal characteristics, generally recognized as part of the concept of the indigenous lands and territories, are taken as necessary in most constitutions and doctrines, with the purpose of keeping indigenous ownership outside the market and free from market forces, guaranteeing intergenerational permanency, and reinforcing indigenous communal forms of use-productive, spiritual, or otherwise..$^{95}$

It is necessary to adopt the three I's to better protect indigenous communities. Currently, compulsory acquisition by the Government overrides other interests in land. ${ }^{96}$ A change in this policy would be necessary for the continuity and prosperity of indigenous people. Besides this, the process of compulsory acquisition is fraught with complications. First is the issue of title. ${ }^{97}$ Where no title to land is evidenced, and this is the case with most indigenous community lands, the Government often takes the land to be public land and occupies it at the expense of indigenous people. This has occurred with respect to the Ogiek and the Sengwer communities and the result has been a massive erosion of the places that hold cultural significance for these communities and in this way, erosion of the communities themselves. ${ }^{98}$ Secondly, the issue of compensation reveals a great misunderstanding of the disparity between indigenous people in Kenya and the rest of the Kenyan people. The values that lie in monetary compensation or relocation prove to be a shallow and misguided reparatory measure for indigenous people that have lost their land.

\section{i. $\quad$ Jurisprudence}

Jurisprudence such as in the Saramaka case can also set guidelines regarding how to solve challenges faced by indegineous peoples. In the case, a large number of communities, residing in South America, that were considered as having the same protection and status as indigenous communities, protested the seizure of their ancestral land by multinational logging and mining companies that had been granted access to the forests in which they lived, by the State. The groups sought legal recourse from the Inter-American Court of Human Rights. The court held that the Saramaka's rights had been violated, that the Suriname Government had a duty to consult and involve them on any potential interference with their land

\footnotetext{
95 — < https://www.wcl.american.edu/hrbrief/10/2kreimer.pdf $>$ on 14 December 2016.

96 Section 28, Registration of Land Act.

97 A requirement in the compulsory acquisition of land as stated in Section 20 of the Land Acquisition Act.

98 Dersso S, Perspectives on the rights of minorities and indigenous peoples in Africa, 316-317.
} 
as well as compensate them for the losses they had incurred. ${ }^{99}$ Of particular interest is the court's directive that the Suriname Government removes measures that impeded the right to protection of the property of the Saramaka.

\section{ii. Legislation}

There is need to issue community land titles to the indigenous communities. There is an even greater need to ensure that their contributions are placed at the apex of the consideration for the allocation of the land and where compensation by allocating other land cannot compensate for the loss of identity, that they be allowed to remain within their recognised land. The Community Land Act has provided for registration of title to communities and this marks a turnaround in the recognition of community land rights most notably for indigenous people. ${ }^{100}$ However, it is not enough to grant indigenous people community title to land as community title does not indicate preference for marginalised communities, it simply states that their land is categorised under community title. ${ }^{101}$ A separate law to specifically demarcate the rights of indigenous people is required. ${ }^{102}$ The Amerindian Act may act as a yardstick for protecting the rights of indigenous people in Kenya. Passed in 2006, the Act protects a community of indigenous people residing in Guyana and gives the community a majority control over their land, recognising the community and its members, their rights over mineral resources within their land, their rights to intellectual property as well as their rights to consultation if Government interference should occur. ${ }^{103}$

John Rawls' second cardinal end to the achievement of justice stipulates that justice must achieve equality of all. However he tacks on the caveat that differential treatment can still meet the end of justice if that treatment is to benefit the least well-off in a given scheme. ${ }^{104}$ In the case of indigenous people living in Kenya, justice must be achieved by allowing true permanence of residence to indigenous groups by suspending the power of eminent domain.

\footnotetext{
99 Saramaka $v$ Suriname, IACTHR Judgment of 28 November 2007 (Preliminary Objections, Merits, Reparations, and Costs), 42-43.

100 Community Land Act (2016).

101 Article 63(d), Constitution of Kenya (2010).

102 For instance, Congo has promulgated a law on the promotion and protection of indigenous populations.

103 Amerindian Act (2006).

104 Rawls J, A Theory of Justice, revised edition, Belknap Press of Harvard University Press, Cambridge, 1999, 27-28.
} 